\title{
Deep endoscopic submucosal dissection of a refractory tracheoesophageal fistula using clip-and-line traction: a successful closure
}

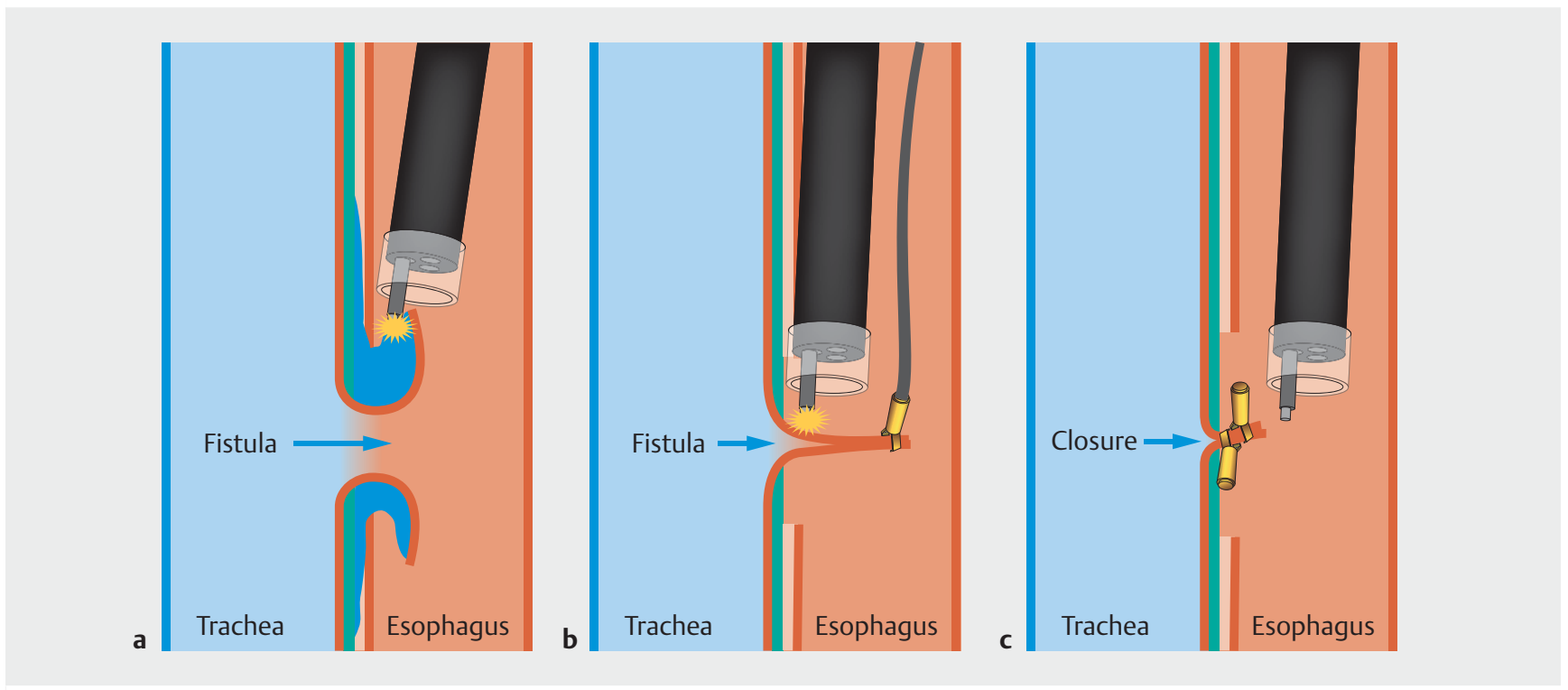

- Fig. 1 Refractory tracheoesophageal fistula: schematic of closure using endoscopic submucosal dissection with clip-and-line traction. a Dissection of a 1-cm patch. $\mathbf{b}$ Clip-and-line traction of the dissected patch and deep section. c Clip closure of the resected area.

Chronic tracheoesophageal fistula is a rare disease presenting a therapeutic challenge. Unlike the case with most digestive fistulas, drainage with a pigtail stent [1] is not possible.

We present here the case of a 47-yearold man referred for a chronic 2-mm tracheoesophageal fistula $(23 \mathrm{~cm}$ from mouth) of unknown cause. His past history revealed several pulmonary infections since childhood.

Several endoscopic treatments were attempted with clip closure and then hot biopsy forceps abrasion of the surrounding mucosa, but complete closure was not obtained. We therefore proposed endoscopic submucosal dissection (ESD) of the surrounding mucosa, namely a $1-\mathrm{cm}$ mucosal patch ( $\mathbf{F i g . 1}$ and - Fig. 2, Video 1) centered on the fistula, as previously described [2].

The patient underwent tracheal intubation with balloon placement just under the fistula. To allow deep dissection of the fistula tract we added a clip-and-line traction ( $>$ Fig.3) [3] to pull the fistula
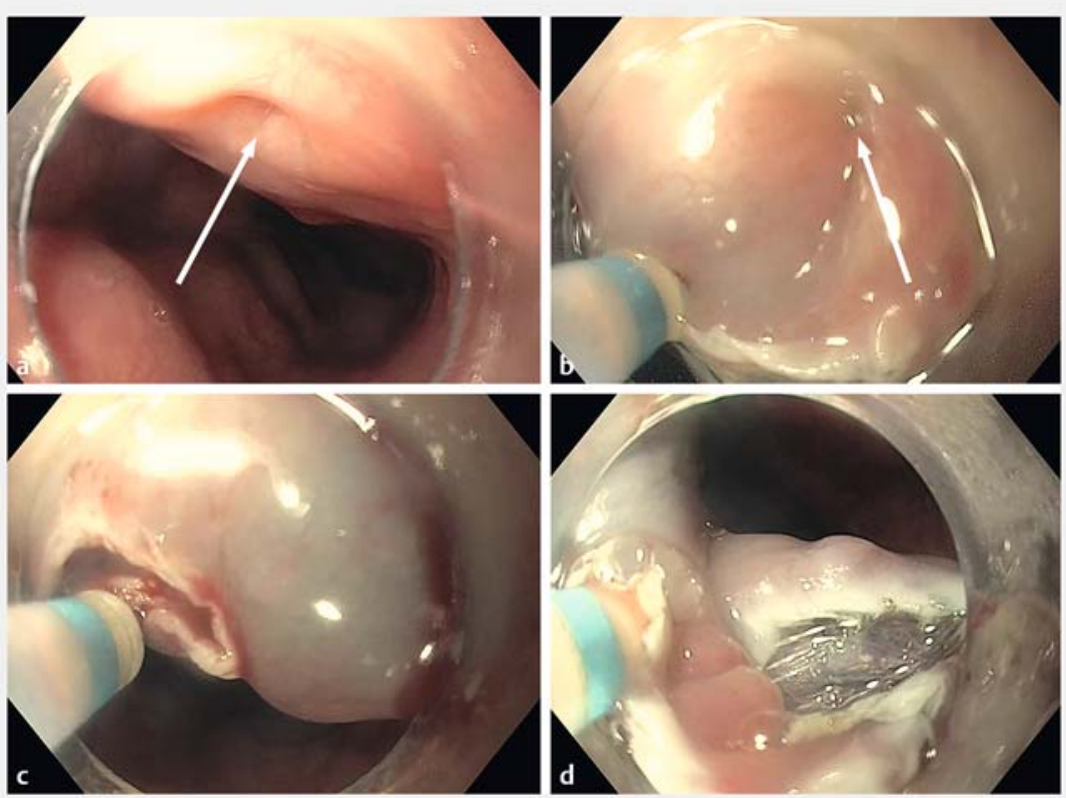

- Fig. 2 Endoscopic submucosal dissection (ESD) of a refractory tracheoesophageal fistula. a Appearance of the fistula before ESD. $\mathbf{b}$ Incision of lower edge. $\mathbf{c}$ Incision of upper edge. d Lateral incisions. 


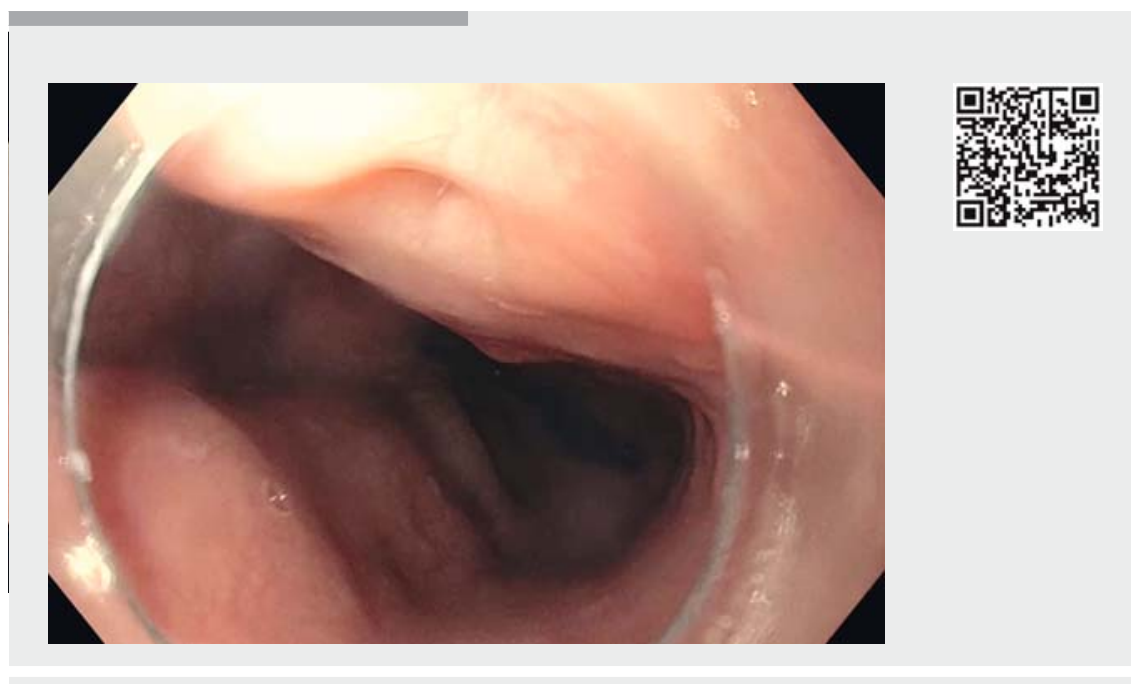

Video 1 Treatment of a refractory tracheoesophageal fistula by endoscopic submucosal dissection of the surrounding mucosa, with clip-and-line traction, and clip closure

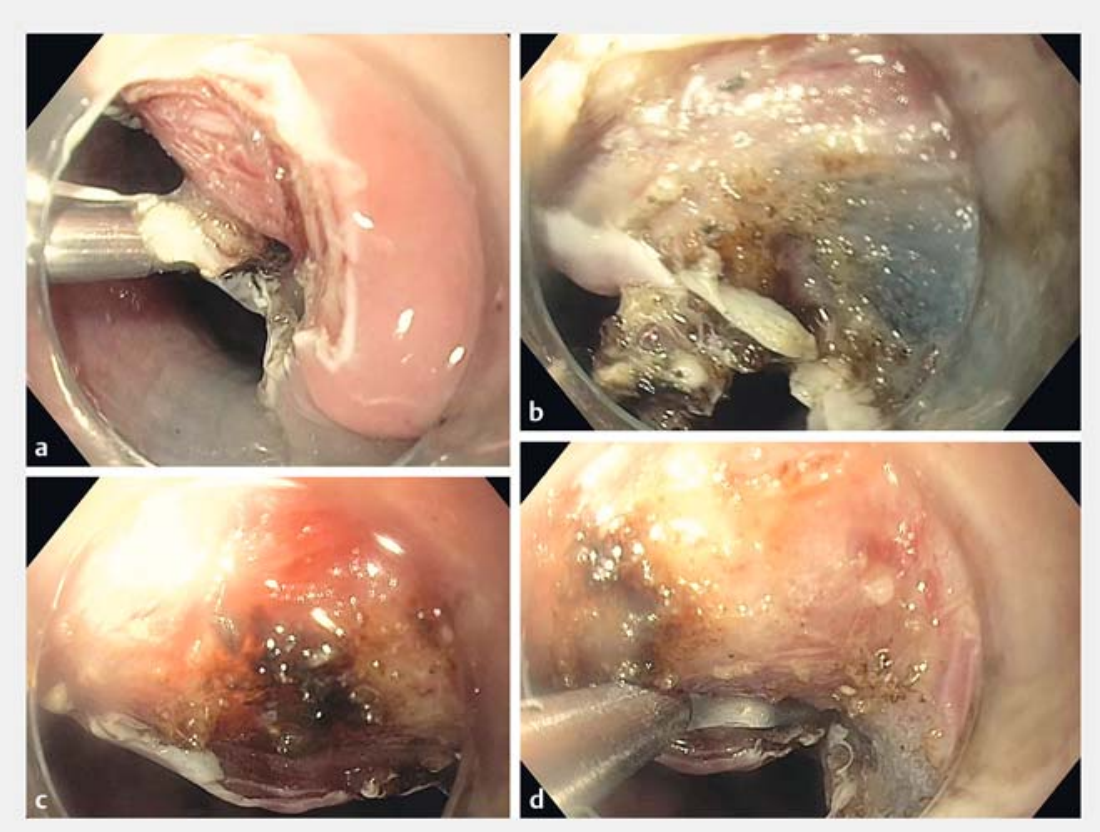

- Fig. 3 Clip traction and closure of tracheoesophageal fistula. a, b Clip-and-line traction of the dissected patch. $\mathbf{c}$ Resected area with burnt fibrosis (black area). d Clip closure.

out of the wall. The fistula tract was then sectioned at the deepest possible point. Finally, we closed the resected area with four clips anchored into the submucosa ( $\triangleright$ Fig.4a,b). A radiographic check was done at the end of the endoscopic procedure, and opacification showed no sign of fistula in the tracheal tract.

The patient's course was rapidly favorable, without pain and with disappearance of aspiration coughing. At 2 months, might be a good option to reduce scarring and to allow definitive resolution of these fistulas.

Endoscopy_UCTN_Code_TTT_1AO_2AI

Competing interests

None

The Authors

Gaspard Bertrand ${ }^{1}$, Jérémie Jacques ${ }^{2}$, Jérôme Rivory', Florian Rostain ${ }^{1}$, JeanChristophe Saurin ${ }^{1}$, Thierry Ponchon ${ }^{1,3}$, Mathieu Pioche ${ }^{1,3}$

1 Department of Endoscopy and Gastroenterology, Pavillon L, Edouard Herriot Hospital, Lyon, France

2 Department of Endoscopy and Gastroenterology, Dupuytren Hospital, Limoges, France

3 Inserm U1032 LabTau, Lyon, France

\section{Corresponding author}

\section{Mathieu Pioche, MD}

Endoscopy Unit - Digestive Disease Department, Pavillon L - Edouard Herriot Hospital, 69437 Lyon Cedex France Fax: +33-4-72110147 mathieu.pioche@chu-lyon.fr

\section{References}

[1] Donatelli G, Chiche R, Cereatti F et al. Endoscopic drainage of intra-abdominal collection after bariatric surgery. Obes Surg 2017; 27: $1635-1637$

[2] Gruner M, Heissat S, Pitiot V et al. Successful endoscopic closure of a refractory button cell tracheoesophageal fistula in a 3-year child using endoscopic submucosal dissection of the surrounding mucosa. Endoscopy 2017: E1 - E3. doi:10.1055/s-0043-113549

[3] Jacques J, Legros R, Rivory J et al. The "tunnel + clip" strategy standardised and facilitates oesophageal ESD procedures: a prospective, consecutive bi-centric study. Surg Endosc 2017 Apr 4. doi:10.1007/s00464017-5514-0. [Epub ahead of print]

[4] Azoulay D, Regnard JF, Magdeleinat P et al. Congenital respiratory-esophageal fistula in the adult. Report of nine cases and review of the literature. J Thorac Cardiovasc Surg 1992; 104: $381-384$

[5] Silon B, Siddiqui AA, Taylor L] et al. Endoscopic management of esophagorespiratory fistulas: a multicenter retrospective study of techniques and outcomes. Dig Dis Sci 2017; 62: $424-431$ 


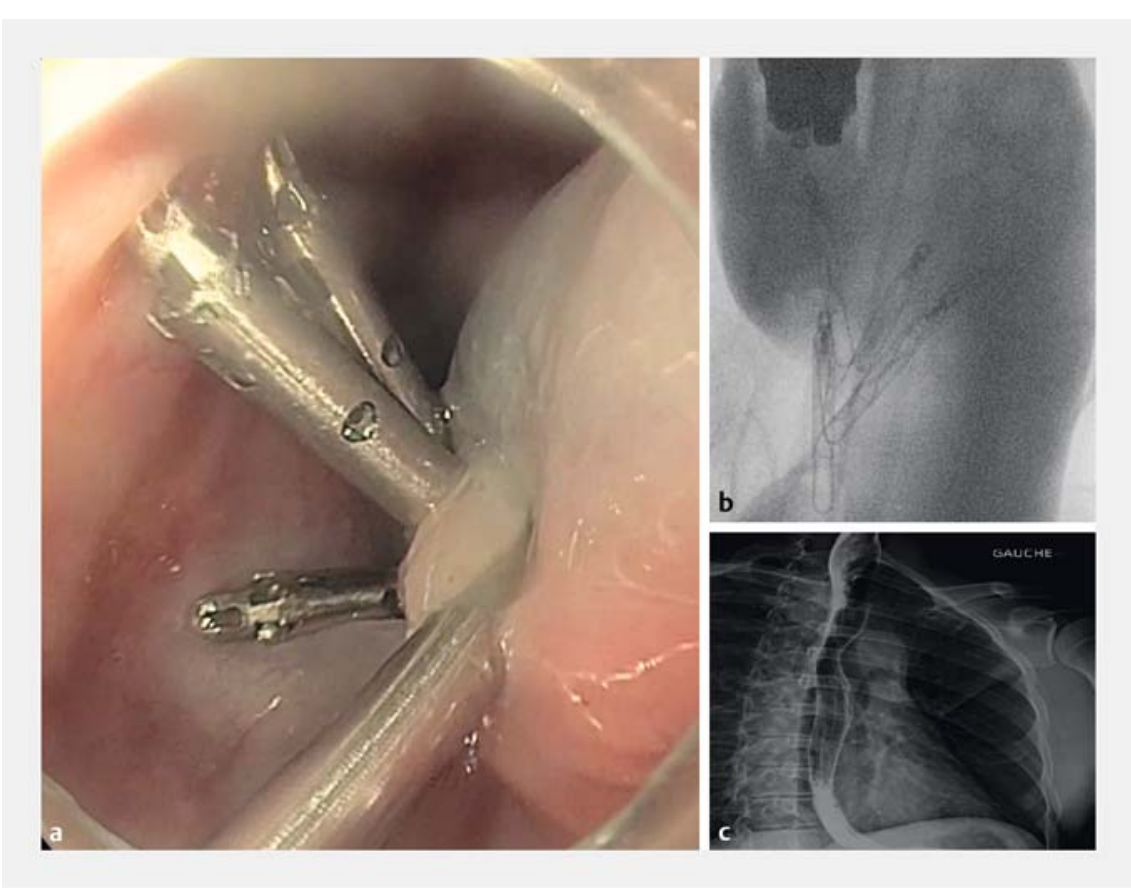

- Fig. 4 End of the procedure for closure of tracheoesophageal fistula. a Endoscopic appearance, with four clips. b Radiographic view showing the clips. c Appearance at radiographic check 2 months later.

\section{Bibliography}

DOI https://doi.org/10.1055/s-0043-119348

Published online: 9.10.2017

Endoscopy 2017; 49: 1278-1280

(c) Georg Thieme Verlag KG

Stuttgart · New York

ISSN 0013-726X

\section{ENDOSCOPY E-VIDEOS}

https://eref.thieme.de/e-videos

回发到 Endoscopy E-Videos is a free y access online section, reporting 靣船: on interesting cases and new techniques in gastroenterological endoscopy. All papers include a high quality video and all contributions are freely accessible online.

This section has its own submission website at

https://mc.manuscriptcentral.com/e-videos 